\title{
Consumption Pattern and Demand Analysis of Dacryodes edulis in Umuahia Metropolis of Abia State
}

\author{
Adenegan K. ${ }^{1}$, Olowoyo F. B. ${ }^{2}$, Ajewole O. I. ${ }^{1}$, Koyejo O. A. ${ }^{2}$, Okelola O. E. ${ }^{3}$ \\ ${ }^{1}$ Faculty of Agriculture/forestry, University of Ibadan, Ibadan, Nigeria \\ ${ }^{2}$ Eastern Research Station, Extension Programme Unit, Forestry Research Institute of Nigeria (FRIN), Ibadan Nigeria \\ ${ }^{3}$ Department of Agricultural Extension \& Management, Federal College of Agriculture, Ishiagu, Nigeria \\ Email address: \\ felixolowoyo@yahoo.com (Olowoyo F. B.)
}

\section{To cite this article:}

Adenegan K., Olowoyo F. B., Ajewole O. I., Koyejo O. A., Okelola O. E.. Consumption Pattern and Demand Analysis of Dacryodes edulis in Umuahia Metropolis of Abia State. Science Journal of Business and Management. Special Issue: Sustainable Entrepreneurial Developments in Agribusiness. Vol. 3, No. 5-1, 2015, pp. 1-6. doi: 10.11648/j.sjbm.s.2015030501.11

\begin{abstract}
Consumption pattern and demand analysis of Dacryodes edulis commonly called ube by the Igbos in Umuahia, Nigeria was studied. The various uses and reasons for consumption of Dacryodes edulis, socio- economic characteristics of respondents, income elasticity, and chi square to determine the relationship between Consumption of Dacryodes edulis and some variables that affect it, are addressed. Simple random sampling was adopted. A well-structured questionnaire were used for Dacryodes edulis consumers at the household in two selected local government areas in Umuahia. A total of (160) one hundred and sixty questionnaires were administered, on a total of eight (8) villages in the city of Umuahia. Data obtained were subjected to simple descriptive statistics, which shows that almost all the respondents $(92.0 \%)$ consume Dacryodes edulis and they got to know of Dacryodes edulis through family and friends due to its high medicinal value as claimed by $91.3 \%$ of the respondents. The income elasticity of Dacryodes edulis demand is $13 \%$. The income elasticity is significant at $5 \%$ with coefficient of 0.13 , this means that a percent increase in income leads to a $13 \%$ of change in Dacryodes edulis consumption.
\end{abstract}

Keywords: Dacryodes Edulis, Demand, Consumption Pattern, Elasticity, Respondents

\section{Introduction}

Edible non-wood forest products are indispensable to rural people for regular or supplementary food supply and as a source of revenue generation. Farmers and forest dwelling people possess a great deal of indigenous knowledge arising from the utilization of non-wood forest products (NWFPS) and agricultural crops (Okafor, 1983). Multipurpose trees and shrubs (MPTS) have multipurpose functions and provide fuel woods, poles, timber, fruits, gums nuts, fiber, medicine etc. for the indigenous people (Anonymous (2010).

Plants are primary sources of medicines, fiber, food, shelter and other items of everyday use by humans. The roots, stems, leaves, flowers, fruit and seeds provide food for animals and human beings (Hemingway, 2004,). Plants serve as indispensable constituents of human diet supplying the body with mineral salts, vitamins and certain hormone precursors in addition to protein and energy (Oyenuga and Fetuga, 1975). Seeds have nutritive and calorific values which make them necessary in diets (Odoemelam, 2005;
Olowoyo 2012). The fruit called ube by the Igbo's or Elemi in Yoruba are economically and medicinally important (Okafor, 1987; Okigbo, 1977). Dacryodes edulis is a traditional food plant in Africa, this fruit has potential to improve nutrition, boost food security, foster rural development and support sustainable land care. The main use of dacryodes edulis is the consumption of its fruit by the people of Umuahia metropolis in Abia State. The fruit can be eaten raw, cooked in salt water or roasted. Cooked flesh of the fruit has a texture similar to butter. The plantation can produce $7-8$ tons of oil per hectare and pulp contains $48 \%$ oil. It is also rich in vitamins. In Umuahia, the kernel is being used as fodder for sheep or goats and the flowers are useful in agriculture, NRC (2008).

Consumption is an act of buying and making use of what you buy as quickly as possible before purchasing another one. According to Robinson (1972), demand is the functional relationship between the price of a given commodity and the quantity of that commodity that will be sold in a market specified as to time and place. Also according to Jhingan (2002), demand in its ordinary meaning means desire but it 
becomes effective when income is spent in buying consumption and investment goods. The essence of the study of demand in economics is to describe the behaviour of consumers. Adegeye and Dittoh (1985), defined demand as a schedule which shows the various amount of a product which consumers are willing to buy and able to purchase at every specific price in a series of time. Demand is classified into individual and market demand. Individual demand is the schedule which shows the various amount of a product which a consumer is willing and able to buy within a particular period of time in a series of possible prices, while a market demand schedule in a particular market can be accomplished by summing the quantities demanded by each consumer at the various possible prices to give the total demand schedule in a particular market (McConnell 1990).

Koutsoyiannis (1979) also defined the market demand for a given commodity as the horizontal summation of the individual consumers. Demand is a multivariate relationship, that is, it is determined by many variables simultaneously. Basically the most important determinants of the market demand are considered to be the prices of the commodity in question, the price of other commodities, consumers' income, number of consumers in the market, consumers' expectation with respect to future prices and income. Keynes in is "General Theory" postulated that aggregate consumption is a function of aggregate disposable income. The relation between consumption and income is based on his psychological law of consumption which states that when income increases, consumption expenditure also increases but by a smaller amount. In other words, the consumption expenditure increases (or decreases) with increase (or decrease) in income but non-proportionally.

The objective of this study is to determine the factors responsible for the consumption of $\mathrm{D}$. edulis and also to determine the pattern of consumption and the various uses and reasons for consumption of Dacryodes edulis.

\section{Methodology}

The study was carried out in eight villages in Umuahia,
Abia State. The city is located on the eastern part of Nigeria and lies between latitude $5^{\circ} \mathrm{N}$ and $7^{\circ} \mathrm{N}$ of the equator, longitude $7^{\circ} \mathrm{E}$ and $9^{\circ} \mathrm{E}$ Greenwich meridian. It comprises of two Local Government Areas (Umuahia North and South) with a total population of approximately 359, 230 (NPC, 2006).

A simple random sampling was used in selecting 160 respondents with just 150 valid for analysis during data collection. The data were collected with well-structured questionnaires. Descriptive statistics such as frequency and percentages were used to analyze the data. In addition, chi square analysis was done to determine the relationship between consumption of Dacryodes edulis and some variables that affect it.

\section{Results and Discussion}

A total of 160 questionnaires were used for this study; but 150 were recovered, from the two local governments. The result of socioeconomic characteristics of respondents is presented in Table 1. Of all the respondents 53.3\% are male and $46.7 \%$ are female. Approximately $29.3 \%$ of them were between ages 36 and 45 years, while $26.7 \%$ were between 46 years and above. About $36.0 \%$ of the respondents claimed to have primary education and $34 \%$ have secondary education. Almost $65.3 \%$ of the consuming respondents are married from major Igbo tribe. Also, from table 1, 28.7\% and 18.7\% of the respondents claimed to be farmers and traders by profession, while $24 \%$ are artisan. Almost $96 \%$ of the respondents are fully engaged in their profession of family trading while 1.3 are not. Almost, $47.3 \%$ of the respondents have between 0 and 4 household family size while $32 \%$ have about 5-8 family size.

Also, 96.0\% agrees that Dacryodes edulis is available in the market all the time, which means it is easily gotten nearby so the consumption is possibly high. It was found out that both wet season and dry season affect the availability of Dacryodes edulis while $76.0 \%$ of the respondents agrees to these. About $54 \%$ of the respondents are still willing to buy their usual quantity weekly even at scarce season.

Table 1. Socio economic characteristics of Respondents.

\begin{tabular}{|c|c|c|c|}
\hline Characteristics & Indicators or operationalization & Frequency & Percentage $\%$ \\
\hline \multirow[t]{3}{*}{ Gender } & Male & 80 & 53.3 \\
\hline & Female & 70 & 46.7 \\
\hline & Total & 150 & 100.0 \\
\hline \multirow[t]{6}{*}{ Age } & $15-25$ & 30 & 20.0 \\
\hline & $26-35$ & 35 & 23.3 \\
\hline & $36-45$ & 44 & 29.3 \\
\hline & $46 \&$ above & 40 & 26.7 \\
\hline & Missing system & 1 & 7 \\
\hline & Total & 150 & 100.0 \\
\hline \multirow[t]{5}{*}{ Educational Qualification } & No formal education & 30 & 20.0 \\
\hline & Primary education & 54 & 36.0 \\
\hline & Secondary education & 51 & 34.0 \\
\hline & $\mathrm{OND} / \mathrm{NCE}$ & 8 & 5.3 \\
\hline & Graduate & 7 & 4.7 \\
\hline
\end{tabular}




\begin{tabular}{|c|c|c|c|}
\hline Characteristics & Indicators or operationalization & Frequency & Percentage $\%$ \\
\hline \multirow{5}{*}{ Marital Status } & Single & 32 & 21.3 \\
\hline & Married & 98 & 65.3 \\
\hline & Widowed & 19 & 12.7 \\
\hline & Single parent & 1 & 7 \\
\hline & Total & 150 & 100.0 \\
\hline \multirow[t]{3}{*}{ Tribe } & Igbo & 148 & 98.7 \\
\hline & Missing system & 2 & 1.3 \\
\hline & Total & 150 & 100.0 \\
\hline \multirow{10}{*}{ Profession } & Medical & 2 & 1.3 \\
\hline & Solicitor & 3 & 2.0 \\
\hline & Teacher & 14 & 9.3 \\
\hline & Farmer & 43 & 28.7 \\
\hline & Trader & 28 & 18.7 \\
\hline & Driver & 20 & 13.3 \\
\hline & Artisan & 36 & 24.0 \\
\hline & Total & 146 & 97.3 \\
\hline & Missing system & 4 & 2.7 \\
\hline & Total & 150 & 100.0 \\
\hline \multirow[t]{6}{*}{ Household size } & $0-4$ & 71 & 47.3 \\
\hline & $5-8$ & 48 & 32.0 \\
\hline & 9 above & 27 & 18.0 \\
\hline & Total & 146 & 97.3 \\
\hline & Missing system & 4 & 2.7 \\
\hline & Total & 150 & 100.0 \\
\hline \multirow[t]{7}{*}{ If yes what is your average annual income } & $0-1$ million & 134 & 89.3 \\
\hline & $1-2$ million & 7 & 4.7 \\
\hline & $2-4$ million & 1 & .7 \\
\hline & $4-6$ million & 3 & 2.0 \\
\hline & Total & 145 & 96.7 \\
\hline & Missing system & 5 & 3.3 \\
\hline & Total & 150 & 100.0 \\
\hline \multirow[t]{5}{*}{ If no what is your other source of income } & Farming & 142 & 94.7 \\
\hline & Trading & 4 & 2.7 \\
\hline & Total & 146 & 97.3 \\
\hline & Missing system & 4 & 2.7 \\
\hline & Total & 150 & 100.0 \\
\hline \multirow[t]{5}{*}{ Did you have other source } & Yes & 13 & 8.7 \\
\hline & No & 133 & 88.7 \\
\hline & Total & 146 & 97.3 \\
\hline & Missing system & 4 & 2.7 \\
\hline & Total & 150 & 100.0 \\
\hline \multirow[t]{6}{*}{ If you have list them } & Farming & 138 & 92.0 \\
\hline & Trading & 7 & 4.7 \\
\hline & Artisan & 1 & .7 \\
\hline & Total & 146 & 97.3 \\
\hline & Missing system & 4 & 2.7 \\
\hline & Total & 150 & 100.0 \\
\hline \multirow{5}{*}{ Is Ube available in the market all the time } & Yes & 144 & 96.0 \\
\hline & No & 2 & 1.3 \\
\hline & Total & 146 & 97.3 \\
\hline & Missing system & 4 & 2.7 \\
\hline & Total & 150 & 100.0 \\
\hline \multirow[t]{6}{*}{ Which season affect the availability of Ube } & Wet season & 20 & 13.3 \\
\hline & Dry season & 7 & 4.7 \\
\hline & Beth & 114 & 76.0 \\
\hline & Total & 146 & 97.3 \\
\hline & Missing system & 4 & 2.7 \\
\hline & Total & 150 & 100.0 \\
\hline \multirow[t]{5}{*}{ At scarce season are you still willing to buy your usual quantity? } & Yes & 81 & 54.0 \\
\hline & No & 65 & 43.3 \\
\hline & Total & 146 & 97.3 \\
\hline & Missing system & 4 & 97.3 \\
\hline & Total & 150 & 100.0 \\
\hline
\end{tabular}

Source: Field Survey, 2010.

In table 2, almost all the respondents $(92.0 \%)$ eat Dacryodes edulis because of its medicinal value, this finding 
concurs with the study by Iduma and Tolawo (2009) where it was reported that all respondents eat because of its medicinal value. A large number of people $(79.3 \%)$ spend about N150.00 weekly on Ube. Most respondents (77.3\%) claimed to know Ube through friends and family, and $85.3 \%$ of the respondents enjoy the fruit being roasted. At each purchase, $44.7 \%$ of respondents bought 15 pieces of Ube.

Table 2. Consumption Pattern of Dacryodes edulis by the Respondents.

\begin{tabular}{|c|c|c|c|}
\hline \multirow[t]{5}{*}{ Did you eat the fruit } & Yes & 138 & 92.0 \\
\hline & No & 11 & 7.3 \\
\hline & Total & 149 & 99.3 \\
\hline & Missing system & 1 & 7 \\
\hline & Total & 150 & 100.0 \\
\hline \multirow[t]{3}{*}{ Reasons for consuming Ube } & Cheapness & 10 & 6.7 \\
\hline & Sweetness & 3 & 2.0 \\
\hline & Medicinal value & 137 & 91.3 \\
\hline \multirow[t]{4}{*}{ How did you get to know Ube } & Thru friends \& family & 116 & 77.3 \\
\hline & Personal likeness/choice & 33 & 22.0 \\
\hline & Thru. Medical practice & 1 & 7 \\
\hline & Total & 150 & 100.0 \\
\hline \multirow[t]{4}{*}{ How best did you enjoy this fruit } & Per boil & 2 & 1.3 \\
\hline & Roasted & 128 & 85.3 \\
\hline & With maize or yam & 15 & 10.0 \\
\hline & All of the above & 5 & 3.3 \\
\hline \multirow[t]{7}{*}{ How often do you buy this fruit } & Daily & 6 & 4.0 \\
\hline & Weekly & 119 & 79.3 \\
\hline & Often & 8 & 5.3 \\
\hline & Seldom & 14 & 9.3 \\
\hline & Total & 147 & 98.0 \\
\hline & Missing system & 3 & 2.0 \\
\hline & Total & 150 & 100.0 \\
\hline \multirow[t]{7}{*}{ What is the price of your purchase each time } & $\mathrm{N} 20-50$ & 22 & 14.7 \\
\hline & N60 - 100 & 15 & 10.0 \\
\hline & $\mathrm{N} 100-200$ & 79 & 52.7 \\
\hline & $\mathrm{N} 210-300$ & 31 & 20.7 \\
\hline & Total & 147 & 98.0 \\
\hline & Missing system & 3 & 2.0 \\
\hline & Total & 150 & 100.0 \\
\hline \multirow[t]{6}{*}{ Quantity purchased at each buying } & 3 pieces & 31 & 20.7 \\
\hline & 15 pieces & 67 & 44.7 \\
\hline & 20 pieces & 34 & 22.7 \\
\hline & Total & 146 & 97.3 \\
\hline & Missing system & 4 & 2.7 \\
\hline & Total & 150 & 100.0 \\
\hline \multirow[t]{3}{*}{ Willingness to buy more Ube Fruit } & Yes & 149 & 99.3 \\
\hline & Missing system & 1 & 7 \\
\hline & Total & 150 & 100.0 \\
\hline \multirow[t]{3}{*}{ With price increase are you still willing to buy your usual quantity } & Yes & 149 & 99.3 \\
\hline & Missing system & 1 & 7 \\
\hline & Total & 150 & 100.0 \\
\hline \multirow[t]{3}{*}{ If the price goes down are you willing to buy more } & Yes & 130 & 86.7 \\
\hline & No & 20 & 13.3 \\
\hline & Total & 150 & 100.0 \\
\hline \multirow[t]{3}{*}{ Number in the household that consume Ube } & All & 142 & 94.7 \\
\hline & Some & 8 & 5.3 \\
\hline & Total & 150 & 100.0 \\
\hline \multirow[t]{2}{*}{ Source of Ube } & Farm field & 6 & 4.0 \\
\hline & Market & 143 & 95.3 \\
\hline \multirow[t]{2}{*}{ S } & Own garden & 1 & 7 \\
\hline & Total & 150 & 100.0 \\
\hline \multirow[t]{3}{*}{ Commercial Importance of Ube } & Potential to increase nutrition & 149 & 99.3 \\
\hline & It boost food security & 1 & 7 \\
\hline & Total & 150 & 100.0 \\
\hline
\end{tabular}

Source: Field Survey, 2010. 
Almost all the respondents (99.3\%) are willing to buy more Dacryodes edulis fruit, even if there is a price increase they still agree to buy their usual quantity. About $95 \%$ of the entire household consume Ube which has market as its source. The major commercial importance of Dacryodes edulis is the potential to increase nutrition $(99.3 \%)$. i.e. for balance diet. The consumption pattern and demand analysis study confirms and builds on previous studies (Ndoye et al., 1997; Tabuna, 2000),
Table 3 shows the cross-tabulation analysis result of consumption of Ube and socioeconomic variables. It can be discovered that consumption of Ube depends on the source of Ube, number in the household that consume the fruit, $(\mathrm{P}<$ $0.05)$. The result therefore implies that increase in the price of Ube will leads to decrease in the quantity demanded, which is the expected situation in any purchase of goods and services. On the other hand, consumption of Ube does not have any correlation with variables such as gender, age $(\mathrm{P}>0.05)$

Table 3. Effect of Selected Variables on Consumption of Dacryodes edulis.

\begin{tabular}{|c|c|c|c|}
\hline & Chi-Square & P-Level & \\
\hline Which season affect the availability of Ube & 31.699 & 0.000 & Significant \\
\hline At scarce season are you still willing to buy your usual quantity? & 5.930 & 0.015 & Ns \\
\hline Consumption Motive & 134.482 & 0.000 & Significant \\
\hline Awareness & 41.749 & 0.000 & Significant \\
\hline How best did you enjoy this fruit & 0.614 & 0.893 & Ns \\
\hline Frequency of Purchase & 43.283 & 0.000 & Significant \\
\hline What is the price of your purchase each time? & 2.790 & 0.425 & Ns \\
\hline \multicolumn{4}{|c|}{$\begin{array}{l}\text { Willing to buy more Ube fruit- this is a constant. } \\
\text { If the price of Ube increase pieces are you still willing to buy your usual quantity }\end{array}$} \\
\hline If the price goes down are you willing to buy more Ube? & 37.561 & 0.000 & Significant \\
\hline Source of Ube & 32.170 & 0.000 & Significant \\
\hline Commercial importance of Ube & 0.080 & 0.777 & $\mathrm{Ns}$ \\
\hline
\end{tabular}

\section{Income elasticity}

The income elasticity of Ube demand is $13 \%$. Income elasticity is significant at $5 \%$ with coefficient of 0.13 , this means that a percent increase in income leads to a $13 \%$ change in Ube consumption. Expenditure elasticity is significant at $5 \%$ with a negative coefficient of 0.07 , this means that a percentage increase in price of Dacryodes edulis leads to a $7 \%$ decrease in its consumption.

The possible reasons for the pasture of the results are distributing of earners. From table 1 it shows that $89.3 \%$ of the respondents have $0-1$ million naira as their average annual income. So Dacryodes edulis in this sense is considered as a luxury which is consumed only when they have money.

\section{Conclusion}

The study provides evidence of a thriving domestic market for Dacryodes edulis in Umuahia as well as valuable Nigeria import market. The result showed that the quantity purchased and price quantity of purchase of Dacryodes edulis each time is positively related to the demand for D. edulis by household. It was also discovered that people consume the fruit majorly because of its medicinal value. A percent increase in income leads to a $13 \%$ change in Dacryodes edulis consumption. The price of Dacryodes edulis varies with the characteristics desired by the market. The key constraint to Dacryodes edulis is perishability and overcoming would help to increase both the domestic and international market. Perishability makes marketing intensity more certain and places a premium on good infrastructure (including cold storage chains for high value marketers) and market information priority should therefore be given to research into storage and processing methods for Dacryodes edulis. All these enhance consumption. The fruit would however have to meet the expectations of current consumers and the requirements of raw outlets, such as generated large - scale supplies frozen fruit and Dacryodes edulis paste may be possible innovations. It is also recommended that Forestry Research Institute Nigeria should perfect more research on the propagation and mass production of this specie to reduce importation from the neighbouring countries.

\section{References}

[1] Adegeye. A .J and J.S Dittoh1985. Essentials of Agricultural Economics. Impact Publishers Ltd. Ibadan

[2] Anonymous, 2010. Dacryodes edulis. AgroForestry Tree Database, World AgroForestry Centre.

[3] Iduma F. O. and O. Tolawo (2009): Demand Analysis and Consumption Pattern of Iru (Dadawa) condiment in Ibadan metropolis. Being a paper published in the proceedings of the $43^{\text {rd }}$ Annual Conference of the Agriculture Society of Nigeria held at National universities Commission Auditorium and RMRDC Abuja in $20^{\text {th }}-23^{\text {rd }}$ October, 2009. Theme: Global food Crisis and Nigeria Agriculture. Pp. 288.

[4] Jhingan M.I [2002].Macroeconomics Theory. Urinda Publishers Ltd 787 pp.

[5] Okafor, J.C., 1983. Varietal delimitation in Dacryodes edulis (G. Don) H.J. Lam (Burseraceae) int. Tree Crops J., 2:255-265.

[6] Olowoyo FB, Kola-oladiji K.I, Adebayo O, Aronu A. J. Okelola O. E. (2012) Consumption pattern and demand analysis of Monodara myristica in Umuahia metropolis in the Forest and Forest Products Journal vol. 5. Pp 1-6. 
[7] Oyenuga V. A. and B. L. Fetuga (1975) First Nutritional Seminar on Fruit and Vegetables. Proceeding and recommended papers NIHORT, Ibadan

[8] Odoemelam S. A. (2005). Proximate composition and selected physiochemical properties of the seeds of African oil bean (Pentaclethra macrophylla) Pak. J. Nutr. 4: 382 -383.

[9] Okigbo, B. H. (1977). Neglected plants of horticultural importance in traditional farming systems of Tropical Africa. Acta Hortic. 53: $131-150$.

[10] National Research Council 1996, Butter Fruit, Lost Crops Of Africa. Vol. 2, cultivated fruits, National Academics Sciences, USA, PP: 363.

[11] Robinson G. 91972). Forest Resource Economics (eds) Ann Arbor Michigan, February 1972.
[12] McConnell, C. R. (1990). Economics Principles Problems and Policies. MC Graw Hill Book Company. 639 pp.

[13] Koutsoyiannis, A.[1973]. Modern macroeconomics Macmillan press London $581 \mathrm{pp}$

[14] NPC (2006). National Population Commission Abuja, Nigeria.

[15] Ndoye, O. Ruiz, Perez, M and Eyebe A. (1997). The markets of Non - Timber forest products in the humid forest zone $22 \mathrm{c}$. ODI, London.

[16] Tabuna, H. (2000). Les products foresteirs non ligned alimental res de L afrique central sur les marches Francis et belge. PhD Thesis, Museum National diffistoire naturelle de paris Tira - Piccos, 